\title{
Literary Autobiography and Subject Formation: A Comparative Study of Mona Enamouri's A Chat upon Thames and Elif Shafak's Black Milk
}

\author{
Dr. Ghada Mohamad Ali Alakhdar \\ Lecturer of Cultural Studies \\ Faculty of Languages \\ MSA University
}

\begin{abstract}
The two novels, Mona Enamouri's A Chat Upon Thames (2014) and Elif Shafak's Black Milk (2007), are autobiographical writings that depict the process of self-representation revealing a postmodern feminist interest in subject formation. Enamouri, on one hand, reflects on the self between places and voices revealing a construction of awareness and self-definition in reaction to external experiences. Shafak, on the other, interweaves a number of questions on female body and identity within the contextual struggle of patriarchical society and intrinsic emotional-personality struggles. Pregnancy and post-partum depression are discussed in line with questions of what it means to have a family, construct a book and determine self-worth. Negotiating a range of feminist thematic preoccupations with voice, spaces, and body the two novels unravel the critical function of feminist autobiographies in constructing the self from "discordant" voices through a dynamic process of self-representation through creation.
\end{abstract}

\section{Key Words:}

Mona Enamouri, Elif Shafak, Aesthetic Subject, feminist autobiography, post-modern subject, women studies, literary autobiography 
السيرة الذاتية الأدبية وصياغة النفس: دراسة مقارنة ما بين ثرثرة فوق نهر التايمز

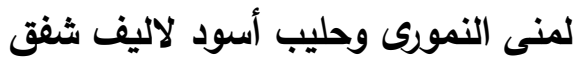

تمثل كلا من الروايتين محاولة لتمثيل النفس فى قالب السيرة الذاتية النسوية

منتهجة بذلك منهج و رؤية نسوية ما بعد حداثية. تنسج منى النمورى فى تنقل شبه دائم ما بين الأحداث والأماكن الوعى اللازم للتحقق من الذات وقبول المتغيرات الثقافية والاجتماعية المختلفة فى محيط تجربة الراوية بينما ترتكز رواية شفق على الهوية النفسية و قضايا الجسد فى مواجهة المجتمع الأبوي إضافة إلى صراعاتها النفسية الداخلية فى حمل واكتئاب ما بعد الولادة- وهكذا تكثف الكاتبة عن محاولات نسويه لإنشاء سياق لقضايا المساحات والأصوات والجسد لتضمين قيمة الذات فى محاولة العطاء العائلى والإنتاج الفكرى جانبا بجنب.

\section{Introduction}

This paper attempts to present a comparative feminist reading, informed by an extensive theoretical scholarship in autobiography, of the memoirs of the traveller and the searching self, Enamouri and Shafak, respectively. The choice, here, of the two texts, A Chat Upon Thames (2014) and Black Milk (2007), reflects several theoretical concerns, and attempts to explore the different motives behind writing a memoir, one in reaction to external experiences and the other to internal experiences. Consequently, the formation of the subject as a choice of self-representation reveals a diversity of critical feminist preoccupations in the light of theories of autobiography. This paper, therefore, attempts to explore the different experiences (external vs internal) that set the driving forces which motivated both Enamouri and Shafak to write their personal accounts or memoirs. How do they define the "uses of autobiography" as pertains to post modern and feminist subject formation? What (feminist) power resides in their writing and how 
Literary Autobiography and Subject Formation: A Comparative Study of Mona Enamouri's A Chat upon Thames and Elif Shafak's Black Milk Dr. Ghada Mohamad Ali Alakhdar

مجلة وادي النيل للار اسات و البحوث الإنسانية والاجتماعية والتربوية (مجلة علمية محكمة)

it drives from and impacts their socio-political context? Autobiography as a form of self-representation is both gendered (expressive of feminist views and voices), and a reflection of experiential variation (constructing the post-modern subject in context of socio-political and cultural norms or abstain from them in given experiences). The process of writing involves an attempt to form the self in terms of awareness and redefine personal knowledge and its limitations while building up agency. The existence of an implicit readership, in the very act of writing, involves a "political dimension." Thus, methodologically, this paper attempts to explore the process of autobiographical "writing" as an expression and means of self/subject formation, in a postmodernist critical feminist reading, touching upon selfawareness and self-representation, through spaces and voices, in order to explore the rich and unique experience of understanding the consciousness of a woman first in reaction to external experiences, as in Enamouri, and then as a deeper externalization of the self on paper, both voicing the intricacies and complexities entailed in their choices.

Both Mona Enamouri and Elif Shafak, are professors of literature motivated to write their experiences in an autobiographical mode. Enamouri wrote her memoirs as an attempt to address and harmonize the socio-cultural differences and make sense of outward experiences during her visit to Britain with her family. The process of constructing her "self" among the many talking women within her, as well as the typical family setting constructed at the end of each chapter, focuses the writing on multiple perspectives allowing for wide-scale negotiations of the external world, meaning and impact of interacting with it. Similarly, Elif Shafak, writes her Black Milk in an autobiographical mode but to "externalize" the different emotions and ideas, aspects of the self, surrounding women and expectations in a struggle to acknowledge her ability to create, both in the biological and the intellectual senses. As she proceeds to deconstruct what comprises 
the self, she reassembles her own story amidst the biographies of other female writers pouring in emotions and imagination on paper. The paper is divided into two parts. The first part launches on key concepts governing my reading of the unique form of women autobiographical writing and the epistemological significance of "memoir" within autobiography theory. In the second part, a lense comparison is employed to discuss Enamouri's formation of the (aesthetic) subject in reaction to a changing context (travel) and the Shafak's in relation to internal struggle over "anxiety of authorship" and post-partum depression. She attempts to unpack and reveal her internal experiences in the process of seeking comfort and answers to construct the self. The two novels will be explored in terms of motivation, subject formation and spaces as well as their female agency constructed via carving a sense of self through anatomizing experiences for self-awareness and autobiographical writing.

\section{Formation of the Subject: Post-modernism and Feminism.}

Post-modernist advocacy of pluralism in morals, politics and epistemology spells out justifications and practices that link the three propositions of post-modernism to feminism. When post modernism announced death of subject (man as not nature, but a social, historical, or linguistic artifact), death of history (reminiscent of Lyotard's "lost nostalgia for the lost narrative"); and death of metaphysics (which is uncertainty and post-truth), feminist literary criticism advocated three counterpoints. For the death of subject, the "demystification of the male subject of reason," was situated. Man is no longer the subject of theoretical and practical reason. Instead, feminists claim that "gender," and practices contributing to its constitution, pertains to the idea of "neutral and universal subject of reason". "His story" is how a reference is made for the "engendering of historical narrative" mostly centered around and written about and for the white Christian male. As for death of metaphysics, "feminist skepticism" introduced distance and critical thinking instead of a dogmatic submission to a transcendental reality. Accordingly, every instance 
Literary Autobiography and Subject Formation: A Comparative Study of Mona

Enamouri's A Chat upon Thames and Elif Shafak's Black Milk

Dr. Ghada Mohamad Ali Alakhdar

مجلة وادي النيل للاراسات والبحوث الإنسانية والاجتماعية والتربوية (مجلة علمية محكمة)

marks of the context out of which they emerge. For feminist theory, the most important "knowledge-guiding interest" in Habermas' terms, or disciplinary, matrix of truth and power ${ }^{1}$ in Foucault's terms, is gender relations and the social, economic, political and symbolic constitution of gender differences among human beings (Benhabib).

Postmodernism is "a theory based on the belief that there can be no such thing as a single, or even a properly privileged, point of view." There is no reliable knowledge of the human world, no well grounded history, personal or collective; all necessary evidence is either culturally conditioned or "constructed" to the point where it offers no access to what was previously thought of as reality and truth (Brosman 97).

Enlightenment claims to universality and pluralism are promoted through post-modernist endeavours were earlier female writings were deconstructed and reposted to the center in order to counter the male-white-money centered "great narrative". Women/ the marginalized/ and the disadvantaged took on a post-colonial stance, especially, when found in already marginalized and disadvantaged position within the postmodern construction of epistemology. ${ }^{2} \mathrm{~A}$ Marxist take points to the matrix of power emanated from the construction of a community, of power and empowerment, and the ethical responsibility of touching the world of the reader and its impact on communal change. The thematic preoccupation of both novels comprises an appreciation of writing the female experience, voicing struggles and an impact or change in readership inline with the spirit of universality of feminist humanism.

${ }^{1}$ Other than rejecting the status quo of male ideological dominance, feminists critics, thinkers and activists sought socio-ideological change to strike gender-based power balance.

${ }^{2}$ The black or Latino woman experience is specific and different from the white-centric female experience harping on the major common theme of power inequality, not just based on gender, but on race, religion and class. 
مجلة و ادي النيل للاراسات والبحوث الإنسانية و الاجتماعية والتربوية (مجلة علمية محكمة)

(ISSN : 2536 - 9555)

Post-modern feminism deploys subject formation and altering traditional autobiographical writings, yet draws on classic roots for the production of knowledge. Constituted by shifting contexts and experiences, a classic critical feminist preoccupation, writing the self echoes the Aristotlian episteme (observation-based knowledge); and, the act of feminist writing itself as praxis, with promises of changing literary autobiographical writing and the external world alongside with its ethical consequences (Neilsen 420). In an attempt to break from Judith Butler's formation of the subject (where sex is nature but gender is context, choice and social practices), the feminist goals of the transformation of the subject proposed by aesthetics refer to the changing experience encountered by the female artist and its epistemological consequences as well as the extent to which these women are affected by it within the (aesthetic) institutions of their production (Hein 23). Challenges for female writers seem to offer a chance for them to utilize the process of writing itself for a sporadic handling of ideas and their theoretical implications.

Critical feminists' preoccupation with awareness of the marginality of women ${ }^{3}$, embracing a duty to shape an alternative to social hierarchies and their Enlightenment ideal of pluralism, equality, autonomy and independence through self-awareness and rejecting traditional stereotypes strategically utilizes postmodernist tools of deconstruction and subject formation and intrinsically conflict with postmodernist disillusionment with the ideals of progress and truths.

Even though self-awareness and delineating female consciousness set out on an exploratory mode, aesthetic writings

${ }^{3}$ Hala Kamal's comprehensive account of early feminist concepts in writing and stereotypes they wished to subvert include women as male property and instrument for acquiring kids and family resources; objectification of women whose only chance of realization takes place via a male figure; the ideal trajectory of female lives proposed by social expectations; and, the good woman narrative for a mother or a patriotic woman. 
Literary Autobiography and Subject Formation: A Comparative Study of Mona Enamouri's A Chat upon Thames and Elif Shafak's Black Milk Dr. Ghada Mohamad Ali Alakhdar

مجلة وادي النيل للار اسات والبحوث الإنسانية والاجتماعية والتربوية (مجلة علمية محكمة)

and episteme embraced post-colonial feminism, in creation of selfawareness via a revisionary process involving acts of resistance, of redefining themselves and the world they had inherited (Olaussen 80).

Ethicality of female self-awareness promoted an interest in consciousness and context of experience and its consequences. In her A Literature of Their Own, Showalter writes "I am intentionally looking ... at the ways in which self-awareness of the woman writer has translated itself into a literary form in a specific place and time-span, how this self-awareness has changed and developed, and where it might lead" (qtd in Olaussen 75).

As early as Gilbert and Gubar, Feminist critics pointed to selfawareness and self-definition as ways to disconnect from mainstream subjectification of women and embraced literary production, especially "writing", "as a process of emancipation", both necessary for and a result of self-determination/agency. Postmodern feminists produced an epistemology for women and about women including appropriating new "4representation", and interplay between the writer as both subject and object of writing and in terms of genre and language.

Exploring female selves with the motivation of creating hermeneutics of experience led to the reconstruction of genre in private space experiences. The stylistics of writing shifted to include journals, diaries, indoor writings, interpolated tales, autobiographical and biographical, stream of consciousness and experimentation writing styles to the literary production (Kamal 23).

Ambitious gynocritical projects to celebrate female agency through self awareness and definition as well as unique styles of writing became a stratifying and marginalizing process when the intersection of disadvantaged experience of a marginalized women

${ }^{4}$ With the highlight of woman as individual with an independent voice, defining female consciousness and the specific female experience of motherhood, love and loss gave female writings significance. 
within a marginalized group was overlooked. Socialist feminist criticism were quick to question "the ideological commitment of feminist critics" exposing both gynocriticism and the earlier mode of "images of women in literature" shifting the focus from an "ethics of fiction", that is studying the impact of text on readers, to the impact of text on political struggle where literature becomes the locus where the real struggle takes place. Black feminist criticism struggle against "false representations" included biographies and authentic experience in the process of finding voice and function within a community. In the process of writing the lived realities for women, intersections of class, race and other group-specific realities/challenges created another writing stream for women. It was albeit criticized for lacking consistent definitions and that amidst fighting stereotyping women and trying to find voice within the community, non-white women claim a position of power and reproduce another representation for women with, of course, ethical consequences for their readers (Olaussen 79).

With centuries long grounded epistemology, the aesthetic subject formation of the woman artist reflects a responsibility to alter real living conditions through an impact on readership. An artist typically reveals an ethnic belonging or a sense of community revealing that epistemological or knowledge based contribution is not the limits of their goal, but rather, change within the community and political based alteration is what they aspire for.

Through her narrative, the female writer creates consciousness necessary for the construction of a community. Alex Deveaux spells out the mission of writing, "writers are given the responsibility of sight... [the] responsibility and beauty of the gift forces us to construct our lives... so we are vehicles to articulate not only our experiences, but the experiences of others" (qtd in Olaussen 70). This very proposition conflicts with postmodernist self writings. "[T]he self, the substance of the would-be autobiographer is viewed as "transindividual," "a mirage, a sum of identifications" (in the words of Jacques Lacan). Warnock writes: "The "I" who was central to Kantian theory, who constructed the world according to a priori laws, has, it is argued, had its day, 
Literary Autobiography and Subject Formation: A Comparative Study of Mona

Enamouri's A Chat upon Thames and Elif Shafak's Black Milk

Dr. Ghada Mohamad Ali Alakhdar

مجلة وادي النيل للار اسات و البحوث الإنسانية والاجتماعية و التربوية (مجلة علمية محكمة)

along with the words themselves." Knowledge of the self is not merely imperfect but impossible, since the self is a collective "construct"; there is no speaker, only a "spoken" (Brosman 97).

Having discussed the feminist aspiration to impact change and the postmodern scattered and objectified self, reconciling feminism and postmodernism allows for exploring the aesthetic subject formation in Enamouri's A Chat upon Thames and Elif Shafak's Black Milk. The female artist undertakes a process of creating meaning out of surrounding or internal experiences, an awareness of a specific time and cultural context, and reveals aspects of a conflicting self as well as identifies the realm of writing as the actual arena for subject formation. In both novels, there is an attempt to build an ethos of belonging to a community of female authors struggling in their writing-hood, womanhood and motherhood. Even the style of writing (using autobiography) is used as a space to carve an individual woman's lived reality for its critical attempts at creating a definition and a construction of meaning of both self and subject to take place (Berryman 72).

\section{Autobiography: Agency in Writing the Self}

Autobiography as an evolving genre is used in line with the evolving critical theories about attempts to define and construct the meaning of self and subject (Berryman 72). Berryman discusses Roland Barthes' autobiography where he evokes a postmodern "disappearance of the individual subject" and the spirit of thinking the "substance" of Roland Barthes himself (both as author and subject) as "totally fictive" (77). Writing becomes "an act of selfcreation" (77); and thus critical theories reiterate the importance of considering the context of writing it as a "construction of the meaning of self and subject" (72).

Berryman points out that it "can be applauded for its creation of multiple and contradictory self-images" (74). In search for the subject as a changing self determined by past/present circumstances, self-definition is attempted through writing the subject, self and author all together in the act of producing text 
مجلة وادي النيل للاراسات والبحوث الإنسانية والاجتماعية والتربوية (مجلة علمية محكمة)

(ISSN : 2536 - 9555)

(81). The philosophical autobiography, as Berryman proposes, becomes more than a retrospective search for the true self. Rather, it becomes an account of a dynamic self assembled amidst different situations and personal tendencies.

Autobiographical writing serves the formation of self through self-discovery and narration. William Howarth defines it as literary genre constructed around character, theme and technique (Jay 39). Paul John Eakin observes, "the relation between self and language [is] a mutually constituting inter-dependency...the rhythms of the autobiographical act [captures]... the fundamental rhythms of identity formation... autobiography emerges as a second acquisition of language, a second coming into being of self, a self-conscious self-consciousness." In other words literature objectifies the self. Beauvoir herself made the remark- self as if it were directed toward the others (Brosman 105).

Critical feminist autobiographies typically ground women where they feel and react essentially different to the world around them. In other words, form and function reflect the unique woman experience. However, a postmodern reading attempts to deconstruct the different layers of the female character/writer and with Hart's deconstruction of the opposition between intended and unintended self representation at the back of our minds (Brosman 100). In an anatomizing approach to the genre, the central problem in post-structuralist reading of autobiography is that of intentionality (Jay 40). Albeit, feminist consciousness can be deciphered through a structuralist method tracing how the narrative is mirrored and shaped by the organization of its formal parts....

Mona Enamouri's A Chat Upon Thames, is comprised of forty chapters and dedicated to " 40 years of chatter". In her attempt to define the self, she covers a classic thematic range of feminist writings, "caught between conflicting cultures" and mediating external experience in language of/for the self (Stoneman 147). The book is a rich experience in language and perspective. The title alludes to Naguib Mahfouz's, a Nobel Prize Winner's book, $A$ Chat upon the Nile (1966) and book has several mentions of Hussein Kadry's The Memoirs of an Egyptian Washing the Dishes 
Literary Autobiography and Subject Formation: A Comparative Study of Mona Enamouri's A Chat upon Thames and Elif Shafak's Black Milk Dr. Ghada Mohamad Ali Alakhdar

مجلة وادي النيل للار اسات و البحوث الإنسانية والاجتماعية و التربوية (مجلة علمية محكمة)

in Britain (1975) as a sign of connecting the book to other writings for "belonging" and empowerment.

Like Shafak, the writer hosts a number of talking female voices who are frequently heard talking to each other or entering in a conversation with her. The different female characters include Radwa Ashour and Sahar ElMougi female Egyptian professorwriters, Amina (the typical oppressed patriarchic woman) and Madame Clean (with a specific preoccupation with hygiene as a motherly figure). The characters negotiate among themselves the experiences, observations and thoughts about the different places she visits allowing for a warm discussion in keeping with the family voice commenting both on the experience and the writing itself in a different moment in time. Her attempt at self formation comes as a rich reflection on outward experiences, English literature, and comparing experiences in Egypt and Britain in a warm, entertaining and humanistic perspective.

The writer interweaves voices and points in time in an agility that allows for comedy and entertaining conversations, as well as digging deep socio-political and cultural issues within the accommodating and warm space of discussions among the voices within her. The scenery in Britain is always a "translated" experience written in Arabic, although an international readership is in mind as she expresses in her book (78). She reflects on Victorian Romantic literature in Lake District, and Harry Potter; and yet, quickly delves into a comparative perspective contrasting behaviours, places, cultures, red-tape and experiences, the good and the bad, in both Egyptian and British cultures revealing a critical post-colonial perception and an open process for negotiating meaning and significance in ways that would give hope and peace to the scattered self.

Warmth and bliss prevail the narrative with many instances of comedy and melodrama, especially that the narrator includes the voices of her family, husband and two teens. The different characters within, books of influence, family members and people they interact with in their different experiences only structurally 
align with her eclectic writing. She blends blogs, travel literature, feminist writings in autobiographical form in the process of discovering the self and other as well as creating new meanings and reflecting on social issues. The writing is vivid and hopeful without any sense of alienation or bitterness amidst experiences of losing personal belongings, over paying at times and struggling to catch a bus here or there for their trips.

The multiple voices allow for a wide range of linguistic competences and chase jargon of scientific, academic or professional reflections on experiences away. She insists on mediating literature and socio-economic and political concepts in a vivid easy to get language, body language and basic one or two word conversations, at times, in order to intensify the inclusive human perspective and anatomize its significance. The writer blends her academic background in English literature and culture with current realities of employment, Arab community issues in the UK and migration. She mediates intricacies of socio-political choices and issues. There's a chapter on the loss of the digital camera that had all the professional and fine pictures only to make the female narrator-mother the only source of documentation of the journey through simple, easy and quick mobile camera shots. This only adds to the easy, commonplace and friendly atmosphere of the novel. An existentialist perspective on "loss" and an associated sense of "void" was raised for a moment only to flow within the light and friendly "chat" or narrative. Losing the professional shots reiterates her agency as the owner of mobile shots reservoir of the trip experiences and the mediator of knowledge on the journey (173-175).

She nodes in appreciation to the guitarist in the busy station (37) and receives respect at the airport from the Indian porter (148) creating a possibility of bonding and living in peace among diversity and the challenges brought by it. The novel proceeds spinning around humanistic moments of interaction, singling out small significant scenes or gestures only to analyze in depth and kindness a variety of implications. From a different point in time, 
Literary Autobiography and Subject Formation: A Comparative Study of Mona Enamouri's A Chat upon Thames and Elif Shafak's Black Milk Dr. Ghada Mohamad Ali Alakhdar

مجلة وادي النيل للار اسات و البحوث الإنسانية والاجتماعية والتربوية (مجلة علمية محكمة)

we hear from the family, at the end of most chapters, another round of jokes, comments and analysis on the same situation.

The process of formation of the subject took place in the process of writing itself, where the writer-narrator refuses to "classify" the writing genre, only to call it "chatter" (205). Albeit, the formal aspect of her writing as a feminist autobiography structured around narrative, character, feelings and imagination allowed her to negotiate concepts, gender roles and reflect on places and literature as the narration smoothly proceeds. The self constructed through self-awareness, processes of discovery and reflection, as well as "owning" knowledge through negotiation and mediation in writing intensify our sense of female agency.

Enamouri's memoir constructs a sense of observation and awareness of the self within socio-cultural challenges and consistent family atmosphere weaving out a humanist sense of peace and bliss combining feminist and postmodern senses of the narrative. It contrasts with the emotional struggle and sense of loneliness in Shafak's writing in her post-partum depression and identity crisis as woman writer vs mother. Both autobiographical writings deploy the women inside the writer's head as means to reflect the post-modernist understanding and expression of tendencies and aspects within the self.

Shafak's account of the little women and their endless conflicts reflect an urge to construct the self amidst the dynamic perspectives and shifting circumstances of the author-subject. The transformation of the subject through everyday lived realities is a common feminist autobiographical theme. "Anxiety of authorship", as put by Gilbert and Gubar, is a favourite

5 The term originally refers to female fear of creation in lieu of the classic "authorship" as authority in Bloom's "anxiety of influence" for male writers exercising full dominance and power over their "imprisoned artistic creatures". They insisted on avoiding Oedipal fixation as a second order "objectification of women", this time at the hands of sons, only to perpetuate their subjectification to men, a favoured methodological perspective for socialist feminism. With an 
مجلة وادي النيل للاراسات والبحوث الإنسانية والاجتماعية والتربوية (مجلة علمية محكمة)

(ISSN : 2536 - 9555)

gynocritical notion describing female writers' struggle and fear of not being able to create.

Interweaving stories/voices of the self means more than the postmodern subjectivities. It can be connotative of the bonding body to the little selves which also pertains to the feminist ideal of women collaborating to realize their empowerment. The collaboration of voices, on both levels, the little women inside Shafak and the female writers' biographies within her, does not come without conflicts, pain and gaps. It becomes the writer's major preoccupation to "voice" the struggle of women and to learn to live in peace and promote tolerance amidst those voices, their diverse choices, and other little women to come.

I dare not say: "There is a mini harem deep down in my soul. A gang of females who constantly fight for nothing and bicker, looking for an opportunity to trip one another up. They are teenytiny creatures, each no taller than Thumbelina... They make my life miserable and yet I don't know how to live without them. They can come out or stay put as they like. Each has declared a different corner of my soul her residence. I cannot mention them to anyone. If I did they would have me institutionalized for schizophrenia. But isn't the personality schizophrenic by definition?'(85).

\section{Spaces, Body and Female Consciousness}

"I can take on any shape I want and still have no shape at all"(45).

Elif Shafak, in Black Milk, takes on anxiety of authorship and creation during her post-partum depression as the central challenge. She chooses to write, in a non-chronological autobiography, the process of defining her aesthetic self over the course of exploring her life, interviewing a prominent female writer and going through thirty eight biographies of female writers with a range of success, failure and loss in their personal lives

awareness of the patriarchic representation of women and their silenced stereotypical delineation in early male writings, an "anxiety of authorship". 
Literary Autobiography and Subject Formation: A Comparative Study of Mona Enamouri's A Chat upon Thames and Elif Shafak's Black Milk Dr. Ghada Mohamad Ali Alakhdar

مجلة وادي النيل للار اسات والبحوث الإنسانية والاجتماعية والتربوية (مجلة علمية محكمة)

within processes of defining their artistic self both as women, wives and/or mothers, and writers.

Instead of seeing the domestic vs the public, Elif delves deeper to negotiate boundaries of body and spaces, and highlights the bathroom as a place where she acknowledges her weakness yet opts for self realization and discovery. First, she rushes to the bathroom to wash her face and freshen up to calm her anxiety after an interview with a prominent writer, talking about the choice of dedicating her life to writing and not to bring children (15). Later, she meets her again at the end of the plot where she settles her selfdiscovery journey and proclaim peace with the multiple and diverse choices of women productivity, be it biological, intellectual, both or none (202).

" $[\mathrm{I}] \mathrm{t}$ is the only place ... where I can have a cigarette-without the others... I set up a mini ironing board in the bathroom as a desk... This is where I write my newspaper column and stories" (145). The bathroom marks first appearance of the "Chorus of Discordant Voices", or the little women in her, each representing an aspect of her character and their natural behavior is to deconstruct and negotiate concepts that pertain to female lives and reflect the process of female consciousness and oscillation between her sense of power and anxiety. It hosts the privacy of her inability to find peace through the different aspects of her character, or "the voices within" as she puts it (200). Accordingly, the autobiographical mode of the narrator as author and actor, starts the process of self discovery and formation in a private and cold ambiance as context of weakness. The conflict within her was "too loud" as the constant arguing refers to the author's sense of anxiety.

Emotions of hesitation and conflict, the bathroom scenes, mostly depict the female-author as lonely, worried and overthinking. With a minimum of conversations throughout the novel, the author's voice finds solace in the supporting presence of other women and intellectual bonding either as interpolated biographies of women-writers within the plot, or as little women 
within her self trying to make sense of her body vs mind conflict with its association of motherhood vs writing books. A conflict that is not only relevant to western white, but also to non-white female writers, where the thirty eight interpolated biographies come from, in sync with the context of Elif Shafak, herself.

Shaking with worry and the incongruity of characters within her, on an aeroplane toilet, she meets Mama Rice Pudding as a new aspect of her character, who points to over eating as a new sense of self, right before she discovers her pregnancy (110). The gradual process of self formation and awareness works hand in hand with probing possibilities for literary production, on the body and the mind levels, just like reading a lot before the production of books, longing for food kicks in before the conception of baby.

At this moment of the narrative, an aspect of the main preoccupation of the narrative poses, as a woman writer, should she identify with the tree she overlooks in the garden or better be a mother. The image of the tree is evoked two more times, when she likens herself to a tree inverted with its roots up in the air, denoting her lack of belonging in a relationship, and the second time in a conflict among the little women, "do you want to be ... [a] forlorn housewife? Or would you rather live your life like a majestic arboreal brain?" (142).

The body as tree, first it is her sense of body "roots up in the air" first time she meets Eyup, then after proposing to her husband, she intellectually ponders on the linguistics of "matrimony com[ing] from the Latin word for "mother" only to find out that "laying down roots is a prerequisite for marriage" (170). It seems she embraces her productive self as tree, an image related to the brain and a geneology of creative production, but now it becomes the creative bonding of "laying down roots" in order to start a family. Ironically, the botanical metaphor is evoked again to reflect a total dismantling of self when challenged.

The formation of the aesthetic subject comes with an identity crisis: What does it mean for a woman to have a different body? In the chapter, "One blue, one pink", she discovers pregnancy. Likening herself to a "shivering leaf", the loneliness of her space is 
Literary Autobiography and Subject Formation: A Comparative Study of Mona

Enamouri's A Chat upon Thames and Elif Shafak's Black Milk

Dr. Ghada Mohamad Ali Alakhdar

مجلة وادي النيل للار اسات و البحوث الإنسانية والاجتماعية والتربوية (مجلة علمية محكمة)

in keeping with her anxiety of authorship and creation, all together. Startled at the news and wondering about the reconstruction of identity it entails is echoed in a chronologically earlier point, but mentioned towards the end of the narrative, when she "shelters" in the bathroom for thirty five minutes on her first date with Eyup. She wished to sense what it means to be in a relationship, only driven out of her "hiding" under the pondering female gaze of other women.

Weakness, hesitation and loneliness of the author reflected in the setting that is private and cold. It emphasizes the female side of worry, infantile attitude when stressed and the demanding and costly process of engaging in family within the bigger question of exploring herself and what it means to be an empowered woman, writer and mother. Instead of claiming power, the aesthetic self of the author is formed in weakness and in "hiding".

One level of resolving the conflict emerges in celebrating author-power even if giving up body. She describes changes in her body and missing out on her monthly menstruation "I am even relieved to be rid of womanhood. Wouldn't it be liberating to free myself of femininity and sexuality, and become a walking brain?'(145). Then, with pregnancy it becomes later harder to accept the body, "Would your writing career decline? Would you be less a woman of letters? You're terrified of being a BodyWoman," Madame Blue belle Bovary, one of the little women, spells out the challenge (158).

At last I've reached a decision between Body and Brain. From now on I want to be only, and only, Brain. No longer will the Body hold sway over me. I have no want for womanhood, housework, wife work, maternal instincts or giving birth. I want to be a writer, and that is all I want to pursue." In this moment, one of the many things I realize is that this is a turning point in my life, a sharp one. While I veer fast, I don't know what awaits me around the corner. "May the Body rot and may the Brain glow. May the ink flow through my pen like oceans to nourish the novels that 
مجلة و ادي النيل للاراسات والبحوث الإنسانية و الاجتماعية والتربوية (مجلة علمية محكمة)

(ISSN : 2536 - 9555)

shall grow within." I repeat this oath three times. When it is over, I feel numb inside, almost anesthetized. Perhaps it is because of the cold. Perhaps the gravity of what I have just uttered has started to sink in (143).

The strength and confidence of picking up an option quickly fades into the conflict set up again. When she chooses to be writer only, she is confronted by the conflict and struggle in defining the contesting aspects of her character as an aesthetic subject. The conflict setting is full of voices either from within or via interaction with other women. The locus of the conflict is always the body. And the modern "Cartesian Self" in state of conflict gives in to a post-modernist dismantling on the hands of the little women in constant movement and thinking within the writer's head.

The question of body expands to include all women. In her diaries of pregnancy, she discovers that "This week I learned that a pregnant woman's body belongs not to her but to all women" (199). Being pregnant takes her from the lonely silent outside to a bonding existence where women give her advice on what to eat and share food and experiences with her. Celebrating the feminist legacy of female writers, obviously, starts with attempts to come at peace with pregnancy/the productive body in a public sphere of women.

The experience of pregnancy reveals double-fold significance for the aesthetic self: it expands the body/mind conflict and emphasizes women bonding for creation. Anxiety comes with pregnancy where questions of guilt, possibilities of failure and fear of giving up writing are voiced:

A cauldron boils in my mind. What if I fail to become a good mother and a good wife? I do not want to betray myself or to pretend to be someone I am not. What scares me most is the possibility of an adverse chemical reaction between authorship and domestic responsibilities. Novelists are self-enamored people who do not like to draw attention to that fact. Mothers, on the other hand, are supposed to be selfless creatures - at least for a while - who give more than 
Literary Autobiography and Subject Formation: A Comparative Study of Mona Enamouri's A Chat upon Thames and Elif Shafak's Black Milk Dr. Ghada Mohamad Ali Alakhdar

مجلة وادي النيل للار اسات و البحوث الإنسانية والاجتماعية والتربوية (مجلة علمية محكمة)

they take. Perhaps I am worrying too much, but worrying comes with thinking. How can I tell my brain not to think? (212).

The detailed experience of pregnancy helps deconstruct the traditional voice within, in the process of self definition and consciousness. Mama Rice Pudding takes the throne, like a "medieval tyrant", and attacks her ambitious empowered womanwriter aspect (with implications of dismantling the aesthetic subject as antagonistic to traditional maternity). Miss High Brow Cynic was attacked and Shafak instructed by traditional "Mama" not to talk to her again, because she is ambitious and reads books. This evokes the patriarchal "good woman" discourse, the classic image of woman as a sacrificing mother, and shifts the personal struggle of Shafak into the bigger socio-cultural significance of her experience within context.

Starting the book on the "Manifesto of the Single Girl", when Shafak claims her writer identity, Mama Rice Pudding subverts the discourse of agency with the earliest signs of pregnancy, "You will bear [morning sickness] just like our mothers and grandmothers and great grandmothers did. What of the peasant woman who gives birth in the fields... She cuts the umbilical cord... and without a single complaint goes back to hoeing the crop" (189). The formation of the aesthetic self is put to test via evoking the traditional stereotyping of women and asking her to accept and follow the traditional cultural baggage in keeping with the changes of body.

"If, historically, women's autobiographies were of necessity written in the private sphere in the form of diaries, letters, personal memoirs, and journals, then our conception of autobiography as a form must accommodate them" (Jay 50). Shafak's "diaries of pregnancy" section has a panorama of mother-female experiences that are common, yet not voiced by the little women or via the biographies of writers. Suddenly, pregnancy shifts the scene from the lonely and cold background reaching out for support whether 
مجلة وادي النيل للاراسات والبحوث الإنسانية والاجتماعية والتربوية (مجلة علمية محكمة)

(ISSN : 2536 - 9555)

through the voices within or through reaching out to the biographies of writers, into the public and bonding experience with stranger women around. The specific Shafak experience localized in the body sets a scope of bonding with the female reader and highlights the gender-specific implications it has through portraying the husband as "bewildered" and unable to unpack the complexity of creation and her anxiety. The common experience of longing, morning sickness, over emotionality and crying, the gap of understanding of her "patient and warm" husband, reaction to scents and her stomach turns, seeing baby sex in the ultrasound and dreams of "pink" associated traditional upbringing for females compile a female-only sense of space based on body experience and intellectual communication. Gynocriticism at its best, female writer critiques biographies of female writers in the literary domain, and offers to bond with female readers and help resolve the socio-cultural problematization of the modern self, womanhood and female writership. ${ }^{6}$

Oscillating self-definitions and shifting roles run in parallel with different political systems attempted to rule the body as the locus of formation for the author subject. Expanding herself cuts the borderline of literature and politics in her autobiographical sense. Like Alice in wonderland, she shrinks to willfully meet the little women within, and expands wide enough to be a country where different political regimes take on. First, it is the "Chorus of Discordant Voices", then a military coup when she was thinking marriage in order to preserve her independent writing powers, then the tyrannical Mama Rice Pudding claims the throne and silences all other voices in a stage that was later followed by depression, only to settle the conflicting existence of the little women in a welcoming democracy.

6 The problem a "woman novelist faces is... whether to sacrifice personal development [and/or] ...self-exploration and accept the dominant culture's definition of what is important to understand and describe"(qtd in Olaussen 80). 
Literary Autobiography and Subject Formation: A Comparative Study of Mona Enamouri's A Chat upon Thames and Elif Shafak's Black Milk Dr. Ghada Mohamad Ali Alakhdar

مجلة وادي النيل للاراسات والبحوث الإنسانية والاجتماعية والتربوية (مجلة علمية محكمة)

"First there was an oligarchy, then it was a coup d'état, inside me. Now a monarchy has come to the Land of Me"(185). During the reign of Mama the Queen, the only readings allowed by the "tyrannical" voice of Mama Rice connotative of tradition are books about baby and mashed baby food and the only allowed learning is prenatal yoga and breathing exercise set the routines for a standard healthy pregnancy and delivery. Voice and silence, the uncertainty of self-definition and attempts for exploring the self and formation of awareness is evident in the pregnancy diaries. "There is a thin line between motherhood and fascism," Miss Cynic Highbrows comments on the phase of silencing the voices under the pressure of production for the body (199).

The voices of little women are mostly silenced, yet again, bonding on the level of body experience, Shafak keeps receiving tips and advice from strangers to the extent that pregnancy to her becomes living in public. The overriding sense of space is private throughout the novel, but once she appears pregnant in public, outdoor scenery and strangers started talking with her revealing a busy city life on the other side of her thinking mind setting. The conflicts within are silenced and women around her bond to promote her creation on the level of body experience.

The body in literary creation, for her, problematizes an epistemological chasm between body and mind that does not get resolved without intersecting the question of sexuality and the cultural conflict it creates in traditional and modern contexts. "In traditional Muslim society ... we women can meet our bodies only inside closets or behind closed doors. The same... is reflected in our storytelling... we women writers, especially those of us from non-Western backgrounds, are uncomfortable about writing on sexuality" (159). Madame Blue Berry Bovary is one of the little women who speak body and sexuality in her. Although the least pronounced, compared to other little female characters, Shafak expands the feminist attempts to write the self in context of modernity and tradition to further highlight the oscilliation between 
مجلة وادي النيل للاراسات والبحوث الإنسانية والاجتماعية والتربوية (مجلة علمية محكمة)

(ISSN : 2536 - 9555)

body and mind until they are settled in the process of the aesthetic subject formation, the literary production and the baby conception.

\section{Agency: female writing as "a woman of excess" not lack.}

"My self-confidence has become a scoop of ice-cream melting fast under the duress of motherhood"---- (200).

Female agency of the writer subject is constructed through a range of actions. Starting with her Manifesto of the Single Girl and probing personal history as well as stories of female writers help unravel the depth of female willpower within silence, patriarchy and female body challenges. She opts out declaring singlehood as the epitome of the writer agency, "divorcing literature is out of the question and since there is no man among mankind who would agree to become "husband number two," in all likelihood, I will be single all my life" (20). Her position was maintained throughout the narrative stressing the double challenge of motherhood and writing as a stressful possibility for production. Negotiating the concepts and oscillating between moments of willpower and bewilderment, female agency was stressed in multiple aspects 'I've traveled wide, I've traveled far, and I've placed writing at the center of my life" (143).

Contrastingly, male agency is completely stripped out with the father figure totally absent in the writer's upbringing. Accordingly, his name becomes no preference in the formation of the aesthetic subject. Over the phone with her publisher, Elif chooses the pen name "Elif Shafak" pairing her first girl name with the female name of her mother, who has taken care of her jointly with the grandmother during her multiple travel and political work. Right from the start, female agency is stressed positioning Elif both as an extension of the liberal nomad traveler female agent as independent, self-sufficient and acknowledging female presence.

Extending agency from acknowledging the mother through claiming her name for the writer identity, Shafak writes to her baby daughter conferring on her the agency of choice. Through a fictive construction of the subject, she imagines the baby choosing her from a catalogue of moms, with the description of "chaotic 
Literary Autobiography and Subject Formation: A Comparative Study of Mona

Enamouri's A Chat upon Thames and Elif Shafak's Black Milk

Dr. Ghada Mohamad Ali Alakhdar

مجلة وادي النيل للاراسات والبحوث الإنسانية والاجتماعية والتربوية (مجلة علمية محكمة)

personality, prone to moments of irrationality, has yet to find herself, is actively searching for answers. Loves telling stories. Writer. Columnist. Litterateur... I don't know why you ended up picking me out of all the potential mothers in the universe"(194).

Marriage and motherhood are tackled with minimal role for Eyup, father of the baby and husband. He does not share in the process of new identity formation, rather, he proposes the help of "another woman" to support wife in his absence. Shafak betrays an ideological rejection of claiming higher power than other ladies for house help. She quickly refers to Virginia Woolf as the loner writer who would write about her household helpers and not write to them but orders on scrap paper. In short, she refuses to live the representation of the writer who receives help from helpers and insists to take care of herself, write and handle her pregnancy, all by herself.

Elif Shafak meets the Latino made, mother of four, her husband disappeared and the barrier of language keeps her from knowing the story. They enjoy coffee, both ethnic and work hard. The writer reflects an awareness of class and economic pressures and offers to quickly and shortly bond with a working class lady who serves coffee.

In four instances, the presence of man is either marginal or negative on the woman. First, the Lesbian couple speaks of their child's "sperm donor" as a philosopher and a person with multiple intelligence and hobbies, starting on a display of family life without the presence of man and also giving voice to the marginalized as the writer accepts her feminist role to balance power in her community. Second, the father name does not make it into her chosen writer name coupling her mother's name with hers instead. Thirdly, she proposes to her husband and he accepts her proposal in an "inverted" classic model scene, yet warm and entertaining (170). Then the hazy and "scared" voice of the husband who is away during her pregnancy and subsequent depression giving way to the formation of her identity in a set up of solitude and discovery. The fourth important male presence comes 
in Part Six of the book when she meets post-partum depression "I am your obedient servant, the Djinni of Postpartum Depression. Otherwise known as Lord Poton"(165). His agency, as a sinster representation for depression given presence and voice, is downplayed with depicting him as old, ghostly, short-sighted and gay. His grip brings her to face her depression and perpetuates control over her through imprisoning her little women in a box and "silenc[ing]" the racing voices in her head. Locking up the little women reduces her presence to the traditional silent, repressed, male-controlled woman and rules out the dynamic diversity of "voices" required for the formation of her self/identity.

Other than exploring the self in relation to men in her real life (father, husband and djinni), a number of encounters of the lives of biographies of female writers show how they handled an aesthetic self in contexts of abandonment, economic pressure, and adversities. Two examples of the what-ifs exploring the possibilities women had if they had experienced a different set of experiences or a less negative male impact on their lives are Zelda Fitzgerald and Tolestoy's wife. Zelda was unhappily married to an equally talented writer, Scott Fitzgerald, and she was driven crazy by their public fights everywhere. He took credit for some of her writings, as insinuated in Black Milk. The what-if comes in when she wonders if both of them could have had a profuse writing life had they had less energy drained in their fights. Zelda died in a mental disorder institution as an example of a talented writer with vast potential only left to suffer and die pathetically. Thinking alternative scenarios help chart out yet negotiate female possibilities for production within their social contexts.

Sophia, the ghost writer and wife of Tolestoy is another example of downplayed female-writer agency. "Her great contribution to Tolstoy's literary legacy was either ignored or belittled... we are beginning to see her in a different light - as a diarist, intellectual and businesswoman - and can appreciate her as a talented, selfless woman with many abilities and unrealized dreams" (63). In reference to her shifting body because of pregnancy, the "Moon Woman" was 16 years his junior and gave 
Literary Autobiography and Subject Formation: A Comparative Study of Mona

Enamouri's A Chat upon Thames and Elif Shafak's Black Milk

Dr. Ghada Mohamad Ali Alakhdar

مجلة وادي النيل للار اسات و البحوث الإنسانية والاجتماعية والتربوية (مجلة علمية محكمة)

him 13 or 19 children was his cook, secretary and ghost writer. She writes seven drafts for War and Peace, yet was unacknowledged and left to die in poverty (58-63).

Sylvia Plath was also unhappily married to Ted Hughes, who was the more famous of the poetic couple. She committed suicide early thirty after giving him two daughters. To this day, Plath's legendary heritage is unsurpassed. Her work is internationally admired and Shafak claims that "no other literary suicide has been talked and written about so much. No other woman writer, after her death, turned into such an icon beyond place and time"(81).

It seems that agency of women is threatened by men, however, throughout the novel her position shifts from condemning male influence to negotiating its impact. In her synopsis on Simon de Beauvoir, she points out that her strong views on marriage and motherhood could have shifted "if Sartre had wanted to have children, in her desire to please him she could have become a mother. She adored him"(115). In De Beauvoir's none compromising dialectic, "the birth of children often goes hand in hand with the death of parents", love becomes a force of creation and even a possibility for change.

The last woman writer she refers to captures the cascading shades of conflict and need for creation.

Hélène Cixous...says her text is written in white and black, in milk and night. Patriarchy, for her, does not exist outside the realm of aesthetics and poetics. She analyzes the Freudian approach that sees woman as "lack," replacing it with "woman as excess." She describes women's writing by using metaphors of childbirth, breast-feeding and allusions to the female body. "It is important to define a feminine practice of writing, and this is an importance that will remain, for this practice will never be theorized, enclosed, encoded-which doesn't mean that it doesn't exist." For Cixous motherhood is a fulfilling experience, the most intense relationship that a human being has with another human being. Though she draws a line between the cultural 
مجلة وادي النيل للاراسات والبحوث الإنسانية والاجتماعية والتربوية (مجلة علمية محكمة)

(ISSN : 2536 - 9555)

and the biological, the latter is not insignificant for her. Female biology is an inspiration for her figurative way of writing. "I'm brimming over! My breasts are flowing. Milk. Ink. Nursing time. ..." ... There is no social change without linguistic change. Women need to break their silence. They need to write. "We should write as we dream," she says (267).

The above quote from the novel makes direct allusion to critical feminist writings with the motivation of constructing female selves within their psychological and biological lives and lived realities. It also points to inventing language and genre, feminist modes of expression, to mediate their emotions, imagination and integrate woman knowledge within epistemology. The process of the formation of the aesthetic subject reveals the struggles that women writers have today.

Conclusion

This comparative study was an attempt to trace the process of aesthetic subject formation of two autobiographical novels. Analysis reveals a critical feminist motivation of self representation and an urge to make a difference in the larger sociopolitical context of writing through voicing female struggles, perspectives and stressing female agency through writing. The post-modern construction of the self as subject and object of writing allows for distance and skepticism for a critical scrutiny of various experiences that transform the subject. While Enamouri's transformation took place on the level of negotiating realities, hoping for socio-cultural integration and largely weaving peace and acceptance around external challenges, Shafak's transformation in reaction to her internal struggles and fear of creation has drastic changes on her outlook and sense of meaning.

Deploying lense comparison reveals the difference of the transformational experiences and spaces for Enamouri and Shafak. Whereas Enamouri sought to shape a bonding humanistic understanding through narrating external experiences and negotiating their meanings within the voices in her head, leading to 
Literary Autobiography and Subject Formation: A Comparative Study of Mona Enamouri's A Chat upon Thames and Elif Shafak's Black Milk Dr. Ghada Mohamad Ali Alakhdar

مجلة وادي النيل للاراسات و البحوث الإنسانية والاجتماعية والتربوية (مجلة علمية محكمة) an accommodation of difference and a sense of peace, Shafak's deconstruction of the subject and anatomizing her beliefs and choices with an overall sense of solitude reflected her internal transformational experiences of identity crisis and anxiety over biological and intellectual production (central theme of the narrative). Elif Shafak's feminist discourse in writing the experiences of the body delineates the particularities of the female experience of dismantling the static intellectual subject through a vivid engagement with reality and a deconstruction of the self in order to form the author and the mother subjects. The double creation or processes of production highlight the schizophrenic aspect of character and the struggle of women in writing and in giving birth.

The cacophony of voices in the writer's head within the two autobiographical narratives, expose the woman as a locus for creating meaning in her attempts at seeking reassurance, communication and solidarity. Both writers embrace body and family in their non-linear literary autobiography that accommodates journal entries, letters, biographies and memoirs as genre as well as their emotionality and flowing imagination.

\section{Reference List}

- Bair, Deirdre. "Simone De Beauvoir: Politics, Language, and Feminist Identity." Yale French Studies, no. 72, 1986, pp. 149-162. JSTOR, www.jstor.org/stable/2930232.

- Benhabib, Seyla. "Feminist theory and Hannah Arendt's concept of public space". History of the Human Sciences, 6: 97, 1993.

- Berryman, Charles. "Critical Mirrors: Theories of Autobiography." Mosaic: An Interdisciplinary Critical Journal, vol. 32, no. 1, 1999, pp. 71-84. JSTOR, www.jstor.org/stable/44029420.

- Black, Naomi and Gail Cuthbert Brandt "Feminism." Feminist Politics on the Farm: Rural Catholic Women in Southern Quebec and Southwestern France. 
مجلة وادي النيل للاراسات والبحوث الإنسانية والاجتماعية والتربوية (مجلة علمية محكمة)

(ISSN : 2536 - 9555)

McGill-Queen's University Press, 1999, pp. 112 143. JSTOR, www.jstor.org/stable/j.ctt811k3.12.

- Brosman, Catharine Savage. "Autobiography and the Complications of Postmodernism and Feminism." The Sewanee Review, vol. 113, no. 1, 2005, pp. 96-107. JSTOR, www.jstor.org/stable/27549636. Accessed 6 Jan. 2020.

- Butler, Judith. Gender Trouble: Feminism and the Subversion of Identity. Routledge 2007.

- DeVault, Marjorie L. "Talking Back to Sociology: Distinctive Contributions of Feminist Methodology." Annual Review of Sociology, vol. 22, 1996, pp. 29-50. JSTOR, www.jstor.org/stable/2083423. Accessed 6 Jan. 2020.

- Dolan, Jill "Cultural Feminism and the Feminine Aesthetic." The Feminist Spectator as Critic. University of Michigan Press, Ann Arbor, 2012, pp. 83-98. JSTOR, www.jstor.org/stable/10.3998/mpub.5169198.10.

- Hein, Hilde. "Why Not Feminist Aesthetic Theory?" The Journal of Speculative Philosophy, vol. 12, no. 1, 1998, pp. 20-34. JSTOR, www.jstor.org/stable/25670236.

- Henking, Susan E. "The Personal Is the Theological: Autobiographical Acts in Contemporary Feminist Theology." Journal of the American Academy of Religion, vol. 59, no. 3, 1991, pp. 511-525. JSTOR, www.jstor.org/stable/1465029. Accessed 6 Jan. 2020.

- Jay, Paul. "What's The Use? Critical Theory and the Study of Autobiography." Biography, vol. 10, no. 1, 1987, pp. 3954. JSTOR, www.jstor.org/stable/23539298. Accessed 6 Jan. 2020.

- Kelly, Maura, and Gordon Gauchat. "Feminist Identity, Feminist Politics: U.S. Feminists' Attitudes toward Social Policies." Sociological Perspectives, vol. 59, no. 4, 2016, pp. 855-872. JSTOR, www.jstor.org/stable/26340185.

- Lerner, Gerda. The Creation of Feminist Consciousness: from the Middle Ages to Eighteen-seventy (New York and Oxford: Oxford University Press, 1993). 
Literary Autobiography and Subject Formation: A Comparative Study of Mona Enamouri's A Chat upon Thames and Elif Shafak's Black Milk Dr. Ghada Mohamad Ali Alakhdar

مجلة وادي النيل للار اسات و البحوث الإنسانية والاجتماعية والتربوية (مجلة علمية محكمة)

- Lovibond S. "Feminism and Postmodernism". In: Boyne R., Rattansi A. (eds) Postmodernism and Society. Communications and Culture. Palgrave, London, 1990.

- Merrill, Cynthia. "Mirrored Image: Gertrude Stein and Autobiography." Pacific Coast Philology, vol. 20, no. 1/2, 1985, pp. 11-17. JSTOR, www.jstor.org/stable/1316510. Accessed 6 Jan. 2020.

- Nielsen, Richard P. "Action Research As an Ethics Praxis Method." Journal of Business Ethics, vol. 135, no. 3, 2016, pp. 419-428., www.jstor.org/stable/24736063. Accessed 9 Jan. 2020.

- Olaussen, Maria. "Feminist Criticism as Ethical Criticism". Critical Survey, Vol. 5, No. 1 (1993), pp. 83-91.

- Overall, "Writing What Comes Naturally?" Hypatia, vol. 23, no. 1, 2008, pp. 227235. JSTOR, www.jstor.org/stable/25483165. Accessed 6 Jan. 2020.

- Sempruch, Justyna. "Splitting the Feminist Subject." Fantasies of Gender and the Witch in Feminist Theory and Literature. Purdue University Press, 2008, pp. 59-118. JSTOR, www.jstor.org/stable/j.ctt6wq72n.6.

- Shafak, Elif. Black Milk: on Writing, Motherhood, and the Harem within. England: Viking Penguin. 2007.

- ---. "Storytelling, Fake Worlds, and the Internet." World Literature Today, vol. 89, no. 1, 2015, pp. 39-41. JSTOR, www.jstor.org/stable/10.7588/worllitetoda.89.1.0039.

- Showalter, Elaine. "Gilbert \& Gubar's The Madwoman in the Attic”. Victorian Studies, vol. 53, no. 4, 2011, pp. 715717. JSTOR, www.jstor.org/stable/10.2979/victorianstudies.53.4.715.

- Staves, Susan. "Women Writers $\neq$ Women Novelists." Tulsa Studies in Women's Literature, vol. 26, no. 1, 2007, pp. 8795. JSTOR, www.jstor.org/stable/20455308. Accessed 6 Jan. 2020. 
مجلة وادي النيل للاراسات والبحوث الإنسانية والاجتماعية والتربوية (مجلة علمية محكمة)

(ISSN : 2536 - 9555)

- Stoneman, Patsy. "Feminist Criticism of 'Wuthering Heights." Critical Survey, vol. 4, no. 2, 1992, pp. 147153. JSTOR, www.jstor.org/stable/41555645. Accessed 6 Jan. 2020.

هالة كمال. مقدمة: النقد الأدبي النسوي والترجمة النسوية. مؤسسة المرأة والذاكرة. .2015

ثرثرة فوق نهر التايمز • دار العين للنشر . 2014 ـ منى النمورى.

سوسن ناجى. صورة الرجل فى القصص النسائي. القاهرة: المجلس الأعلى للثقافة .2006 